\title{
AIRBORNE UHF RADIO ECHO-SOUNDING OF THREE YUKON GLACIERS
}

\author{
By B. B. Narod and G. K. C. Clarke \\ (Department of Geophysics and Astronomy, University of British Columbia, Vancouver, \\ British Columbia, Canada V6T I W5)
}

\begin{abstract}
A high-resolution radio echo-sounder operating at a frequency of $840 \mathrm{MHz}$ has been developed for airborne sounding of small and medium-sized polar glaciers and ice caps. The sounder uses a compact, high-gain antenna which suppresses valley-wall echoes and simplifies operation from light aircraft. Successful field trials were carried out on Rusty, Trapridge, and Hazard Glaciers, Yukon Territory, Canada. Results compare well with ice depths obtained from earlier ground-based soundings on Rusty and Trapridge Glaciers. The maximum ice thickness encountered was $200 \mathrm{~m}$ on Hazard Glacier.

Owing to the high operating frequency, random scattering from inhomogeneities within the ice is a major cause of signal degradation. For this reason the sounder cannot penetrate great thicknesses of temperate or debris-rich ice. Spatial averaging, an immediate result of operating from a moving platform, reduces the effects of back-scattered "clutter".

RÉsumé. Sondage aérien par écho radio UHF de trois glaciers du Yukon. Une sonde par écho radio à haute résolution opérant dans une fréquence de $840 \mathrm{MHz}$ a été mise au point pour le sondage aérien de glaciers polaires et de calottes glaciaires petits et moyens. La sonde utilise une antenne compacte à haute performance qui supprime les échos des parois des vallées et simplifie les opérations à bord d'un avion léger. Des expériences de terrain fructueuses ont été menées à bien sur les glaciers Rusty, Trapridge et Hazard dans le territoire du Yukon au Canada. Les résultats se comparent bien avec les profondeurs de glace obtenues lors des plus récents sondages terrestres sur les glaciers Rusty et Trapridge. L'épaisseur maximum de glace rencontrée était de $200 \mathrm{~m}$ sur le Hazard Glacier.

En raison de la haute fréquence à laquelle on opérait, la dispersion aléatoire à partir des irrégularités de structure interne de la glace est une des causes majeures de dégradation du signal. C'est pourquoi la sonde ne peut pas pénétrer sur une grande épaisseur de la glace tempérée ou riche en moraine. Le "lissage" spatial des résultats, conséquence immédiate du fait que l'on opère à partir d'une plateforme mobile, réduit les effets du "bruit de fond" réfléchi.

Zusammenfassung. UHF-Radar-Echosondierungen von drei Yukon-Gletschern aus der Luft. Zur Sondierung kleiner und mittelgrosser Gletscher und Eiskappen in der Polarregion wurde ein Radar-Echogerät hoher Auflösung mit einer Arbeitsfrequenz von $840 \mathrm{MHz}$ entwickelt. Das Gerät verwendet eine kompakte Hochleistungsantenne, die Echos von den Talwänden unterdrückt und die Messung mit leichten Flugzeugen vereinfacht. Erfolgreiche Versuche wurden am Rusty, Trapridge und Hazard Glacier, Yukon Territory, Kanada, durchgeführt. Die Ergebnisse stimmen gut mit den Eisdicken zusammen, die bei früheren Sondierungen vom Boden aus am Rusty und Trapridge Glacier gewonnen wurden. Die festgestellte maximale
Eisdicke war $200 \mathrm{~m}$ am Hazard Glacier.

Infolge der hohen Arbeitsfrequenz bildet die zufällige Streuung an Unregelmässigkeiten im Eis eine starke Quelle für Störungen des Signals. Das Gerät kann deshalb nicht dicke Schichten von temperiertem oder schuttreichem Eis durchdringen. Die räumliche Mittelung als unmittelbare Folge der Operation von einer bewegten Plattform aus vermindert die Wirkung des rückgestreuten "Wirrwarrs".
\end{abstract}

\section{INTRODUCTION}

In 1973 we began development of a radio echo-sounder for use in northern Canada. The need to operate on small glaciers dictated the sounder's properties. We chose $840 \mathrm{MHz}$ in the ultra-high-frequency (UHF) band as the centre frequency for several reasons. Although dielectric losses and random scattering increase with frequency, a high-gain antenna can offset much of the loss: the small size of a UHF antenna simplifies airborne operation. Most Canadian polar ice masses are expected to be within the maximum range of a UHF sounder.

In August 1976 we tested the sounder on three glaciers in the Steele Creek basin, St Elias Mountains, Yukon Territory, Canada. Extensive glaciological work had previously been done on two of these glaciers, Rusty and Trapridge Glaciers, so the thermal regime and ice depth were known at a number of sites; a network of survey markers provided ground control points. To get similar information about Hazard Glacier we set up a field camp and carried out a levelling survey, ground-based experiments with the radar, hot-water drilling, and ice temperature measurements. Later in August, using a Bell 206 helicopter, we did the aerial 
surveys of these glaciers. Our results from Rusty, Trapridge, and Hazard Glaciers, which we present here, confirm that aerial UHF radio echo-sounders can function well on smaller cold ice masses, and that the technique can provide complete ice-thickness data with relative ease.

\section{BAGKGROUND}

Development of UHF ( $300 \mathrm{MHz}-3 \mathrm{GHz}$ ) radio echo-sounders has lagged behind that of sounders operating at the lower $\mathrm{VH}$ frequencies $\left(3^{0}-300 \mathrm{MHz}\right)$. Greater dielectric losses and higher susceptibility to scattering have limited the usefulness of UHF sounders on large polar ice sheets, the first regions of extensive radio echo-sounding. Waite (1966), using an SCR-7 8 $440 \mathrm{MHz}$ aircraft altimeter in north-west Greenland, reported loss of signal at depths exceeding $400 \mathrm{~m}$. VHF sounders have no difficulty sounding ice many times this thickness. On small and medium-sized valley glaciers, valley-wall reflections and aircraft manoeuvrability, rather than ice penetration depth, are the main considerations; thus the small size and directivity of UHF antennae become attractive.

In 1970 on Roslin Gletscher, Davis and others (1973) used a UHF sounder to measure ice thicknesses in a cold valley glacier. Man-hauling a modified SCR 7 I 8 radio altimeter they were able to measure ice thicknesses up to $400 \mathrm{~m}$; all previous soundings using the SCR 718 had been made on polar ice caps. They reported that scattered returns at many locations often made identification of a distinct bottom echo difficult (Smith and Evans, 1972).

The first UHF radar designed strictly as an ice-depth sounder was a $620 \mathrm{MHz}$ instrument built for the Department of the Environment of Canada (DOEG) by Goodman (1975). Results of man-hauled surveys of Rusty and Trapridge Glaciers demonstrated that the DOEC system was capable of finer resolution than VHF systems, and that valley-wall echoes and rapidly varying bedrock topography did not seriously affect the sounder's performance. As with the SCR 7 18, internal scatterers could have made the identification of a distinct bottom echo ambiguous.

The University of British Columbia (UBC) radio echo-sounder, which is similar in concept to the DOEC system, has been specifically designed to sound the smaller polar glaciers and ice caps found in northern Canada (Narod, unpublished). Its centre frequency is $840 \mathrm{MHz}$, bandwidth $40 \mathrm{MHz}$, and system performance is $124 \mathrm{~dB}$. The $35 \%$ increase in frequency over that of the DOEC system brings increased susceptibility to internal scattering and higher dielectric losses, but these drawbacks are offset by the high gain and small size of the antenna and the ease with which the entire system is made airborne. Surface echograms demonstrate that scattering returns vary greatly with minute changes in antenna position (Bailey and others, 1964). By moving the antenna while continuously recording, the relatively constant bottom echo can be identified among the highly variable scattering returns. When airborne, the scattering returns vary too rapidly to be visible on an oscilloscope phosphor.

\section{INSTRUMENTATION}

The UBC echo-sounder comprises a transmitter, receiver, circulator, antenna, and oscilloscope display. Table I lists relevant system parameters; complete system details will appear in a forthcoming doctoral thesis. The system performance of the radar transceiver (transmitter, receiver, and circulator) is $124 \mathrm{~dB}$. Adding the two-way antenna gain of $3 \mathrm{I} \mathrm{dB}$, the effective system performance is $\mathrm{I} 55 \mathrm{~dB}$. Both the transmitter and receiver are internally protected against abnormal power surges caused by cable failures. A $120 \mathrm{MHz}$ signal from a crystal oscillator is multiplied to $720 \mathrm{MHz}$ and $840 \mathrm{MHz}$ to provide the local oscillator and carrier frequencies respectively. The carrier is then amplified, gated, and isolated at the $4 \mathrm{~kW}$ level. The circulator is a three-port ferrite device which allows the system to operate with a single antenna. The receiver input is protected by a solid-state limiter. The signal is converted 
TABle I. System description and Parameters

Transmitter: Gated dual microwave cavity triode amplifier. Frequency is set by crystal

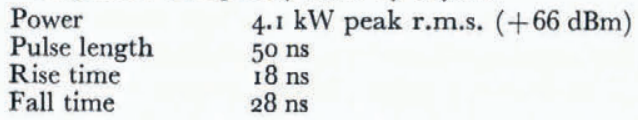

Receiver: Thin-film solid-state hybrid. Logarithmic response

Bandwidth

Intermediate frequency $\quad$ I $20 \mathrm{MHz}$

Dynamic range $80 \mathrm{~dB}$

Sensitivity $\quad-70 \mathrm{dBm}$

System losses $\quad$ I $2 \mathrm{~dB}$

(including I.F. conversion loss)

T/R switch: Passive circulator

Isolation $25 \mathrm{~dB}$

I dB bandwidth $\quad>40 \mathrm{MHz}$

Antenna: Two-dipole colinear array with a third parasitic element and a $90^{\circ}$ corner reflector I dB bandwidth

VSWR $>40 \mathrm{MHz}$

Forward gain

Depth

I. 14

$15.5 \mathrm{~dB} \pm \mathrm{I} \mathrm{dB}$

Width

Length

Weight

$0.30 \mathrm{~m}$

$0.59 \mathrm{~m}$

$1.18 \mathrm{~m}$

General:

Total system weight $\quad 50 \mathrm{~kg}$

Power required $28 \mathrm{~V}$ at io $\mathrm{A}$

Estimated maximum range in cold ice $650 \mathrm{~m}$

to the $120 \mathrm{MHz}$ intermediate frequency and filtered. The I.F. amplifier-detector has a logarithmic response characteristic with a useful dynamic range of $8 \mathrm{o} \mathrm{dB}$.

The antenna is a $90^{\circ}$ corner reflector with two driven dipole elements. Its measured forward gain is I $5.5 \pm \mathbf{1} .0 \mathrm{~dB}$. The estimated $E$-plane and $H$-plane half-power beam-widths are $18^{\circ}$ and $44^{\circ}$ respectively. The antenna is compact enough to be attached to the cargo hook of any helicopter with high skid gear. On our August 1976 flights we outrigged the antenna from the helicopter in an experimental installation.

The video output from the receiver modulates the phosphor intensity of a Tektronix model 475 oscilloscope. A slow ramp on the vertical input scans the trace through the full screen height in one minute. The operator manually controls the vertical scan and a Polaroidbacked oscilloscope camera records the data. This results in approximately $20 \%$ of lost coverage by dead time. (In future, we plan to replace the photographic recording system by a magnetic recorder and graphic recorder.)

\section{SURVEY PROCEDURE}

As well as the arrival time of the bed echo, useful sounding data require knowledge of aircraft position and ground clearance. The UBC sounder, when used as its own radio altimeter, receives a strong echo from the ice surface. It is necessary, however, to fly at least $40 \mathrm{~m}$ above the ice surface in order to separate the transmitted pulse from the first received pulse. The small dynamic range of the phosphor and film cause this limitation. An improved recording system could reduce the minimum required elevation to less than $25 \mathrm{~m}$ above the ice 
surface. Alternatively, flying as close to the surface as possible, the pilot can use visual references (survey markers, etc.) to control his elevation and maintain a constant clearance above the ice surface. The advantage of the latter procedure is a greater signal-to-noise ratio (Swithinbank, I968). Its disadvantages are several: reduced air speed, reduced accuracy (the pilot cannot maintain a perfectly constant height above the surface; we have estimated our low-level height at $6 \pm 2 \mathrm{~m}$ ) and poor flight-line photography--not to mention discomfort due to air sickness and increased risk of crashing. Data for Rusty Glacier were collected from high elevation (Figs I and 2); data from Trapridge Glacier were collected from both high and low elevations; data from Hazard Glacier were collected only at low elevation.

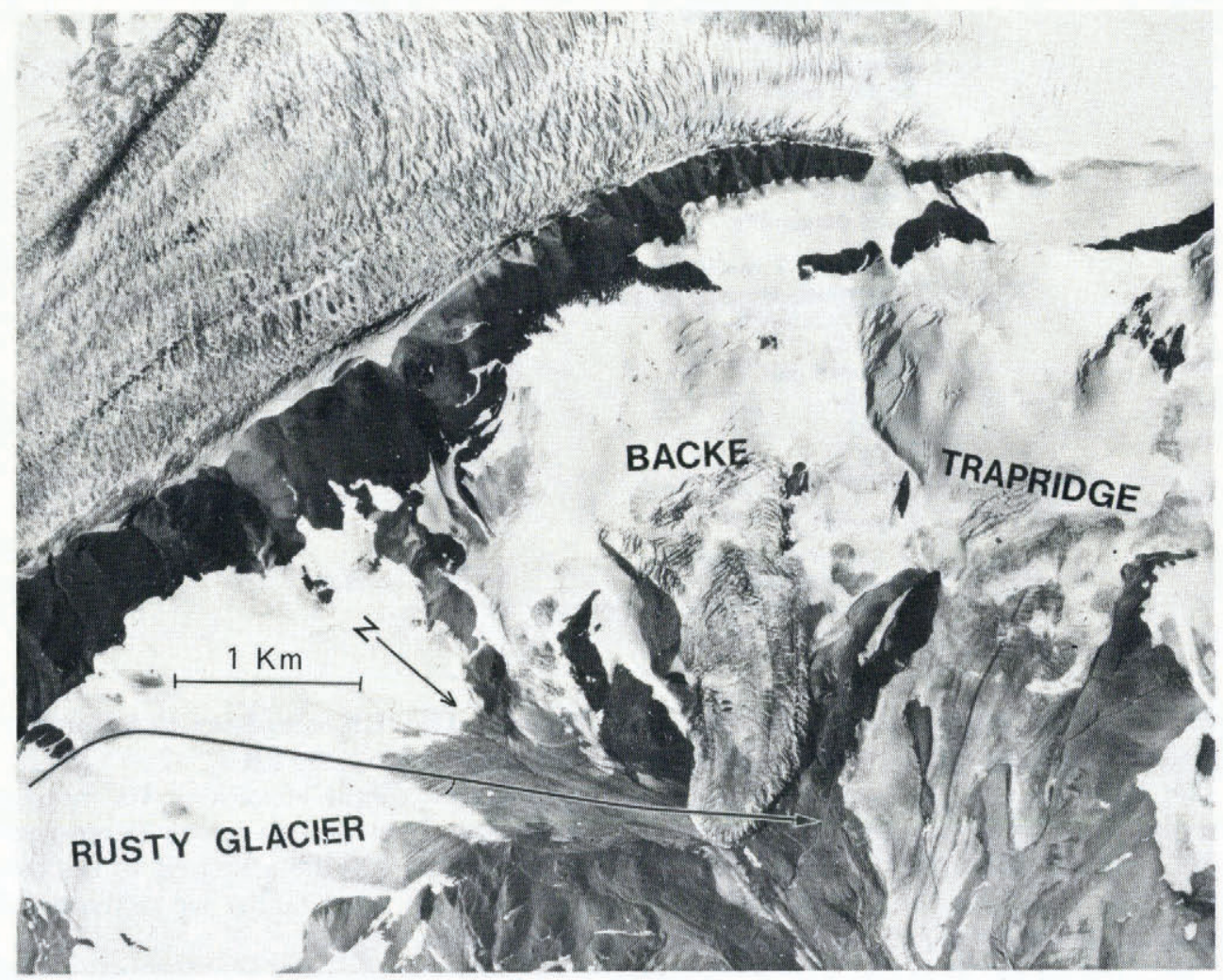

Fig. I. The fight path of the profile reproduced in Figure 2. The region shown is at lat. $61^{\circ} 15^{\prime} \mathcal{N}$., long. $140^{\circ} 20^{\prime} W$.

For flight-line records we used a combination of dead reckoning and aerial photography. A tape recording of the aircraft intercom was verbally synchronized with the data collection. Navigation information included compass headings, airspeeds, and visual references. Aerial photography with a $210^{\circ}$-coverage fish-eye lens was also synchronized with the data collection. Our intention was to take photographs every io s, which, when compared to large-scale photographs, would provide locations and headings (Fig. 3). Unfortunately photographic flight control was incomplete due to erratic behaviour of the motor-driven Nikon camera caused by aircraft vibrations (the camera has now been replaced by a $70 \mathrm{~mm}$ Vinten aerial reconnaissance camera). We have estimated our plan accuracy at better than $50 \mathrm{~m}$ for accepted data. Complete survey details will appear in a forthcoming doctoral thesis. 


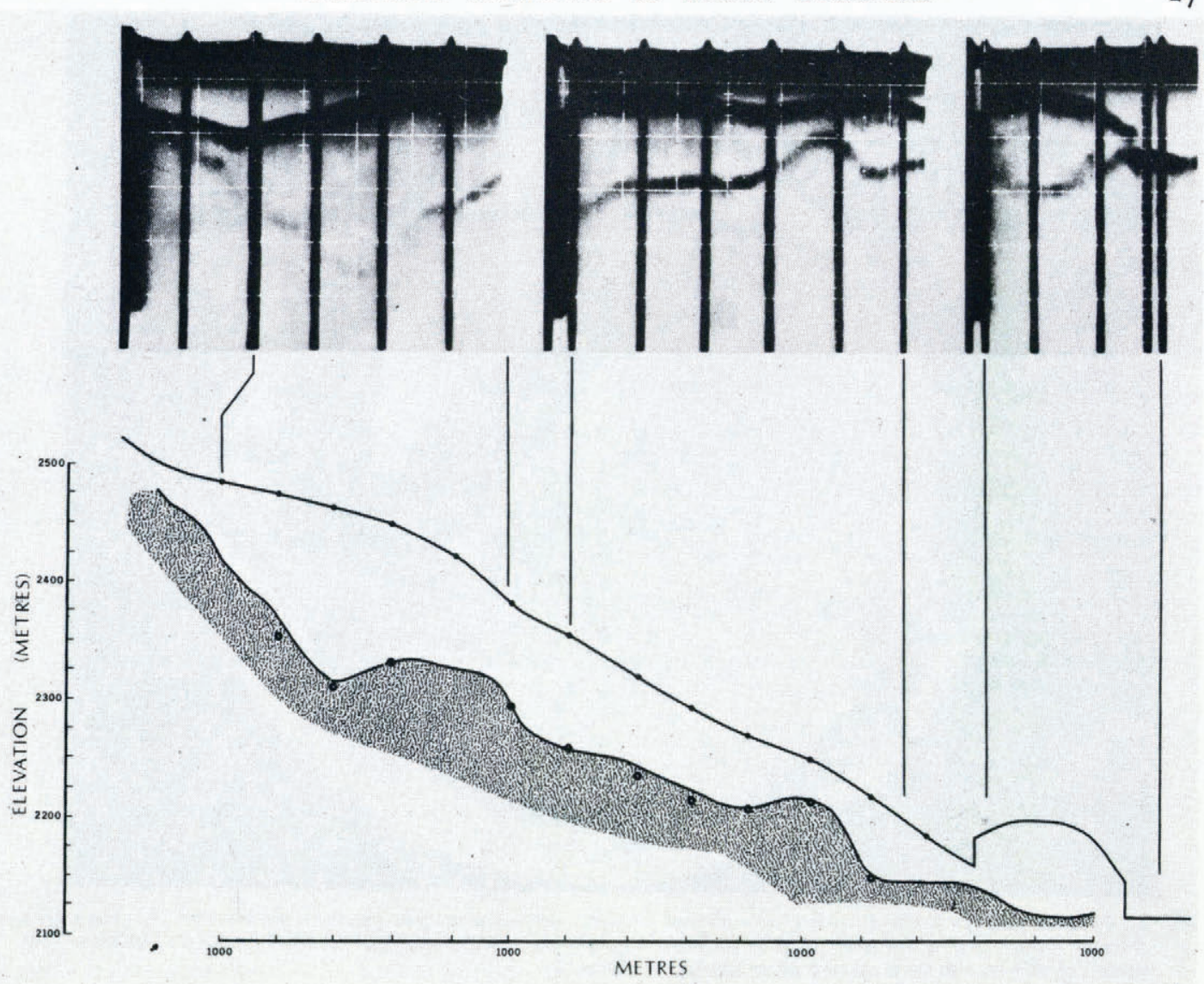

Fig. 2. Cross-section of Rusty Glacier showing photographically recorded data. The small circles at the ice surface represent the centre-line survey stakes. The larger circles at the bedrock boundary indicate the ice depths measured with the DOEC system (Clarke and Goodman, 1975). Vertical exaggeration is $4: 1$. The data records show clear separation of the transmitted pulse, ice-surface reflection, and ice-bottom reflection, even over ice as thin as $30 \mathrm{~m}$. The dark vertical bars are synchronizing marks with the $35 \mathrm{~mm}$ camera or with verbal cues recorded on the flight recorder. The vertical scale is $500 \mathrm{~ns}$ division $^{-1}$. Data for the cross-section were compiled from two passes of identical plan and overlapping profile (one not shown).

\section{RESUlts}

The profile of Rusty Glacier presented in Figures I and 2, except for crossing the terminus of Backe Glacier at the lower end, follows the centre line of survey markers down the glacier. The profile is in excellent agreement with an earlier survey made by man-hauling the DOEC system (Clarke and Goodman, 1975). For ready comparison with this work we have taken $176 \mathrm{~m} \mathrm{~s}^{-1}$ as the velocity of electromagnetic waves in ice. At the ten locations where direct comparison is possible, seven of the measured ice depths agree within the resolution of the system. The remaining three discrepancies, all less than $10 \mathrm{~m}$, have been attributed to a deviation of the flight path near the headwall, or to difficulties of interpretation of ground survey data. It is also possible that the airborne system could yield data implying shallower ice, since it illuminates a larger area of the bedrock.

The Rusty Glacier profile demonstrates several features of the echo-sounder. Resolution (about $4 \mathrm{~m}$ or one-tenth of a graticule division) is currently limited by the photographic 


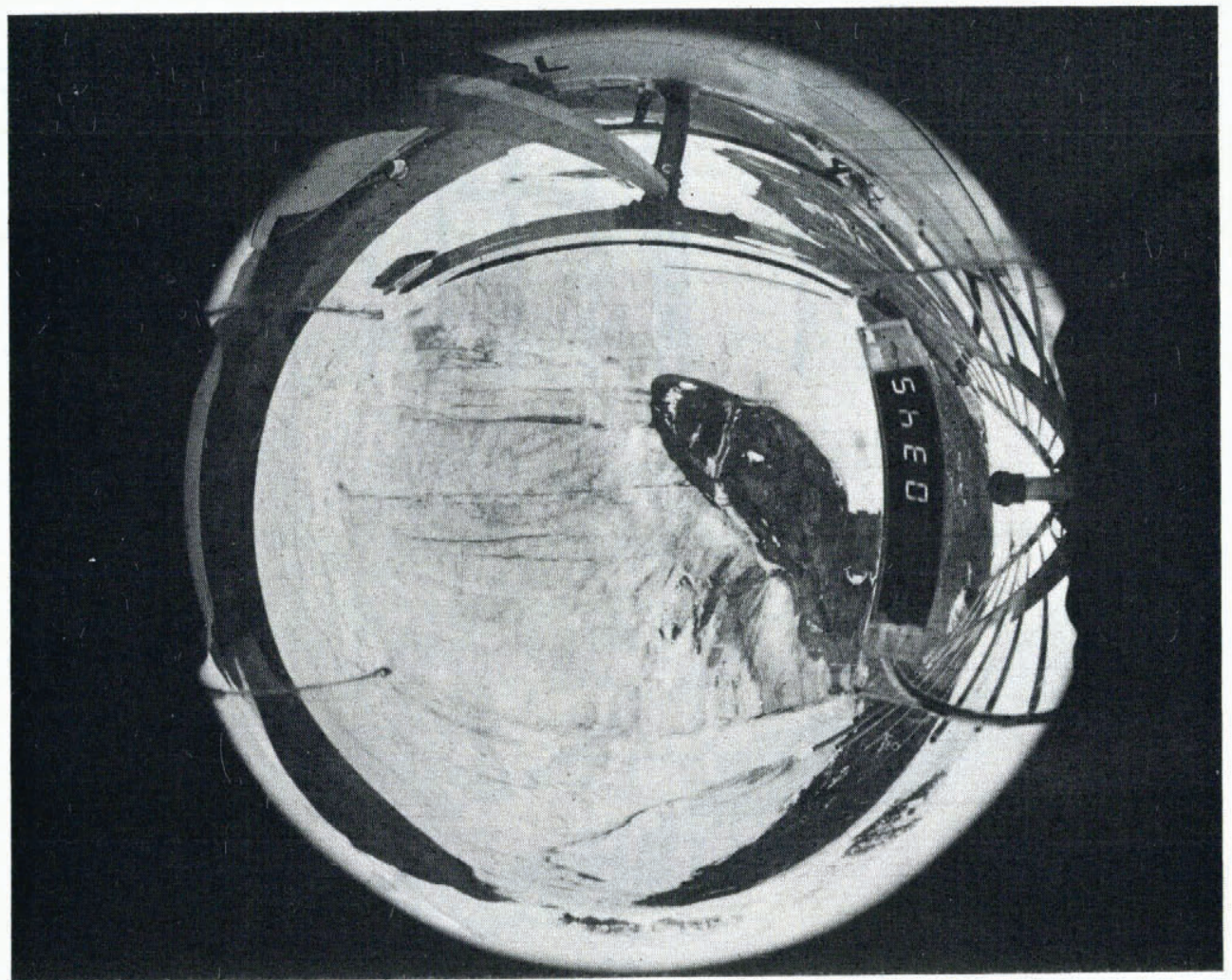

Fig. 3. An aerial fish-eye photograph taken over Hazard Glacier. These photographs provide flight-line control. The surface drainage feature seen in this photograph is visible on a government aerial photograph taken at ${ }_{5} 5000 \mathrm{~m}$ elevation. The location of this photograph is marked by an asterisk on Figure 5 .

recording scheme. The averaging effect of the photographic film suppresses scattering returns since each grain is exposed by the accumulated output of over I 000 transmitter pulses.

Data for the ice-thickness map of Trapridge Glacier (Fig. 4) were compiled from three of the four flights made during the two days, resulting in more extensive coverage than on Rusty Glacier. Trapridge Glacier also has an array of survey markers useful during the flights as visual navigation aids. Again, where it is possible to compare the airborne ice-thickness measurements with those made from the surface with the DOEC system (Goodman and others, 1975), agreement is very good, within the resolution limit of the present airborne system.

There are a number of features in the new ice-thickness map that were not indicated by the ground-survey data. A shallow rib extends from the northern edge, about half-way up the glacier, across the glacier towards an ice fall. This zone of shallow ice may split the glacier into two separate dynamic zones. The major rock ridge which splits the terminus extends under the ice about one-third of the way up the glacier. A basin of ice has been found between the two rock spurs near the centre of the headwall. The new features are consistent with the ground-survey data and are results of the more extensive coverage of our airborne programme.

The most serious limitation of the sounder is its inability to penetrate great thicknesses of temperate or debris-rich ice. We believe the ice-thickness map of Hazard Glacier (Fig. 5) owes much of its character to an internal moraine layer formed by the merging of the glacier's two main tributaries. The map shows, along the northern edge of the glacier, a shallow ledge of relatively constant $(60-80 \mathrm{~m})$ ice depth. The boundary of the ledge is defined by a tortuous 


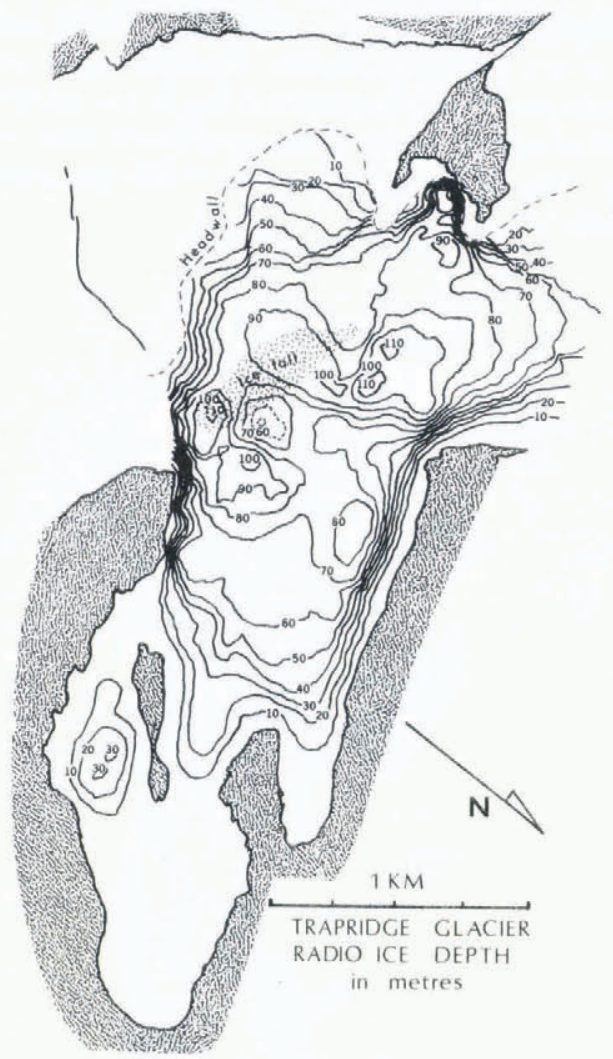

Fig. 4. Trapridge Glacier ice-thickness map. The contours are computer generated by interpolating from the airborne data onto an arbitrary square grid. The interpolation uses an inverse-distance-squared weighted average of the nearest datum in each of eight equal sectors. In regions of low density coverage and particularly near the south-west headwall, the map reflects the arbitrary nature of the interpolation scheme.

$80 \mathrm{~m}$ ice-depth contour. We do not believe that in this region we have actually measured total ice depth. More likely the radiation has been scattered by an internal moraine layer.

The evidence for an internal reflector is two-fold. Each transverse flight line yielded data showing an extremely steep rise from the "deeper" southern region of the glacier to the northern ledge (Fig. 6). These very strong boundary points do not define a smooth valley floor. Instead they cause the tortuous $80 \mathrm{~m}$ contour in Figure 5 . We believe that the rises are too steep for a reasonable valley configuration and that the irregular contours result from the occasional penetration of the radiation through the internal layer. Secondly, the edge of the shallow ice depths coincides with the major surface medial moraine. The structure which has caused the formation of the medial moraine could also have caused the formation of an internal moraine layer which terminates in the vicinity of the medial moraine. Possibly ice from the northern arm has overridden ice which originated at the southern headwall.

\section{Concluding Remarks}

Our field tests demonstrate that airborne UHF echo-sounders can be used to measure the ice thickness of small and medium-sized cold valley glaciers. The compact size of the antenna and instruments makes them easily deployable from even the smallest aircraft. Using a small 
helicopter, complete ice-thickness data can be collected quickly and efficiently. The deepest ice encountered was $200 \mathrm{~m}$ on Hazard Glacier, though this is not the depth limit of our sounder. During an airborne survey of the glacier lying in the north-west col of Mount Logan, Yukon Territory, we sounded $430 \mathrm{~m}$ of ice under conditions that were far from ideal (Clarke and Narod, unpublished). The major drawback of UHF echo-sounders is their inability to penetrate temperate or dirty ice.

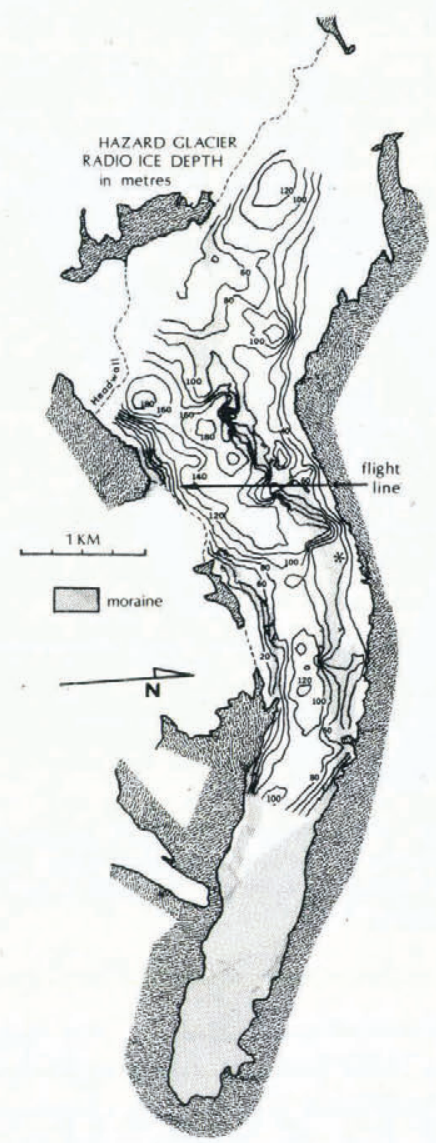

Fig. 5. Hazard Glacier ice-thickness map. The contour interval is $20 \mathrm{~m}$. The major medial moraine is shown as a shaded area. The asterick marks the location of Figure 3.

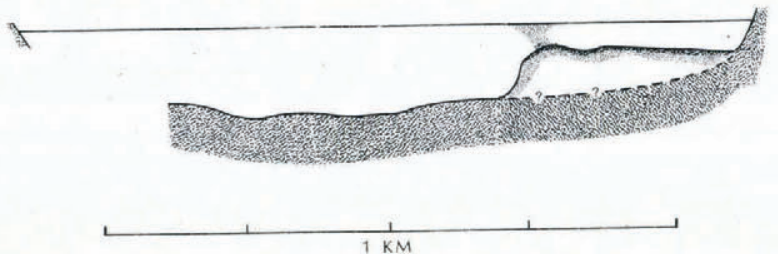

Fig. 6. A transverse section of Hazard Glacier. The cross-section is shown looking up-glacier, with the northern boundary to the right. The fight line shown on Figure 5 went from the northern boundary to the southern boundary. The steep rise coincides with the edge of the major medial moraine. The shallow ledge is probably not bedrock but a debris layer, perhaps brought with overlain ice from the northern arm of the glacier. 
Several improvements to the sounder are in progress. These include the organization of the radar into a single rack-mounted package for easier airborne deployment, increased pre-amplication for improved system performance, addition of a graphic display for monitoring and field replay, a magnetic recorder for digital or analogue data, and directrecording navigation aids.

\section{Acknowledgements}

We thank the National Research Council of Canada, Environment Canada, and the University of British Columbia Committee on Arctic and Alpine Research for financial support. Dr R. H. Goodman was generous with his time and advice. We are grateful to Parks Canada for allowing this work to be undertaken in Kluane National Park. While conducting the aerial surveys we were based at the Kluane Research Station of the Arctic Institute of North America; we thank the Institute for logistic support extending over many field seasons.

MS, received 24 November 1978 and in revised form 12 March 1979

\section{REFERENCES}

Bailey, J. T., and others. 1964 . Radio echo sounding of polar ice sheets, by J. T. Bailey, S. Evans, and G. de Q. Robin. Nature, Vol. 204, No. 4957, p. 420-2I.

Clarke, G. K. C., and Goodman, R. H. 1975. Radio echo soundings and ice-temperature measurements in a surge-type glacier. Journal of Glaciology, Vol. 14, No. 70, p. $71-78$.

Clarke, G. K. C., and Narod, B. B. Unpublished. Mt Logan radar survey, or the operation was a success but the patient died. [Internal report, Dept. of Geophysics and Astronomy, University of British Columbia, Vancouver, Canada, September 1976.]

Davis, J. L., and others. 1973 . Radio echo sounding on a valley glacier in East Greenland, by J. L. Davis, J. S. Halliday, and K. J. Miller. Fournal of Glaciology, Vol. 12, No. 64, p. 87-91.

Goodman, R. H. 1975. Radio echo sounding on temperate glaciers. Fournal of Glaciology, Vol. 14, No. 70, p. $57-69$.

Goodman, R. H., and others. 1975. Radio soundings on Trapridge Glacier, Yukon Territory, Canada, by R. H. Goodman, G. K. C. Clarke, G. T. Jarvis, S. G. Collins, and R. Metcalfe. Gournal of Glaciology, Vol. I 4, No. 70,

Narod, B. B. Unpublished. UHF radio echo sounding of glaciers. [M.Sc. thesis, University of British Columbia, 1975.]

Smith, B. M. E., and Evans, S. 1972. Radio echo sounding: absorption and scattering by water inclusion and ice lenses. Journal of Glaciology, Vol. 1 i, No. 61, p. $133-46$.

Swithinbank, C. W. M. 1968 . Radio echo sounding of Antarctic glaciers from light aircraft. Union de Géodésie et Géophysique Internationale. Association Internationale d'Hydrologie Scientifique. Assemblée générale de Berne, 25 sept.7 oct. 1967. [Commission de Neiges et Glaces.] Rapports et discussions, p. 405-14.

Waite, A. H., jr. I 1966 . International experiments in glacier sounding, 1963 and 1964 . Canadian Journal of Earth Sciences, Vol. 3, No. 6, p. 887-92. 